This is a preprint of the brief report for special issue "The new style of psychological research:

CHANGE we can believe in" of Japanese Psychological Review.

資料論文

\title{
「事前登録の事前審査」経過報告と所感
}

\section{Progress report and opinion of "pre-review of pre-registration"}

\author{
三浦麻子 (大阪大学) \\ Asako Miura (Osaka University)
}

要約

近年, 心理学研究の再現性危機が叫ばれている。本特集号では, こうした状況を少しでも良化さ せるための処方箋の 1 つとして, 先行研究の直接的追試の「事前登録の事前審查」を実践した。こ の資料論文では, 日本では初めて行ったこの実践について, 経過報告と審査者による所感を通して まとめ, 今後を展望した。

キーワード: 再現性, 事前審査, 事前審査つき事前登録論文, 直接的追試, 2 段階審査

\begin{abstract}
In recent years, there are severe concerns about the replicability and reproducibility crisis of psychological research. In this special issue, as one of the remedies to improve this situation as much as possible, we practiced "pre-review of pre-registration" of direct replication of previous research. In this paper, I summarized our practice, which was performed for the first time in Japan, through a progress report and comments by the reviewers, and provided some perspectives for the future.
\end{abstract}

Keywords: Replicability, Pre-registration, Registered Report, direct replication, Two-stages review 


\section{概 要}

本特集号では, 心理学研究の再現性危機が叫ばれる中, 事態を少しでも良化させるための処方 箋の 1 つとして, 先行研究の直接的追試の「事前登録の事前審査」を実践した。事前登録(preregistration)とは, 研究者が, 研究に着手する前に, 実施する計画 (サンプルサイズや分析方法 など）を明確かつ詳細に定めて第三者機関に登録することである。そして, 単に研究者が事前 登録をするだけではなく, 掲載を希望する学術誌にそれを投稿し, 学術誌側はその内容を審査 した上で，掲載を前提とできる研究に着手させる。これが事前登録の事前審査(pre-review)である。 そしてその成果が投稿されれば，掲載に值するかどうかが再度審査され，採択されれば掲載に至る。 あくまで成果を対象とするのみであった従来の論文審査に, 計画段階での審査が加わる 2 段階審 查方式をとることで, HARKing (Hypothesizing After the Results are Known; 仮説の後づけ)やい わゆる「 $n$ 増し」のような仮説を支持する統計的に有意な結果を得んがためのサンプルサイズの調整 といった QRPs (Questionable Research Practices; 問題のある研究実践)を抑止しようとする意図が 込められている。こうした審査を経た論文のことをRegistered Report(RR)と称する。本論文では, 三 浦が担当編集委員 (友永雅己氏・原田悦子氏・山田祐樹氏・竹澤正哲氏・三浦 ${ }^{1}$ ) を代表して, 日 本の心理学系学術誌では初めて行ったこの実践について, 経過報告および審査者による所感を通 してまとめ, 今後を展望する。

\section{企画発動から公募まで}

本特集号の企画が立ち上がったのは 2018 年 7 月である。『心理学評論』編集委員会での審議・ 承認を経て, 特集号 Web サイトを開設し2，同年 11 月末から事前登録の公募を開始した。特集号 の刊行タイミングが 2020 年初頭に固定されていたので, 刊行までのスケジュールを表 1 のように設定 した。また, 事前登録とは別に招待論文 2 編の執筆を依頼し, 本特集号企画に対するコメント論文 と事前登録を含まない資料論文の投稿は，11 月末を期限として随時受け付けた。第 2 段階の最終 締切をそれ以外の種別の論文よりも早く設定したのは，掲載決定後に個別論文に対するコメント論 文を付すことを計画していたことによるものである(結果的にその計画は実現できなかった)。

\section{表 1 当初設定の刊行スケジュール}

\begin{tabular}{|l|l|l|}
\hline 段階 & & 日程 \\
\hline \multirow{3}{*}{ 第1段階 (事前登録) } & 論文投稿 & 2019年2月末 \\
\cline { 2 - 3 } & 審査結果通知 & 2019年3月中旬 \\
\cline { 2 - 3 } & 最終締切 & 2019年3月末 \\
\hline \multirow{3}{*}{ 第2段階 } & 論文投稿 & 2019年7月末 \\
\cline { 2 - 3 } & 審査結果通知 & 2019年8月中旬 \\
\cline { 2 - 3 } & 最終締切 & 2019年8月末 \\
\hline
\end{tabular}

1 このうち友永氏と三浦以外は『心理学評論』編集委員ではなく, 本特集号に限ったゲストエディタ ーである。

2 特集号 Web サイト http://team1 mile.com/sjpr62-3/ 


\section{第 1 段階審査}

事前登録論文は 3 月 4 日までに 5 編が投稿された。これらについて, 専門領域が近い担当編集 委員 1 名以上がアクションエディタとなり, 外部審查者 2 名を選定して, 共に(ただし, それぞれ独立 して) 第 1 段階審査にあたった。三浦はすべての審査に関わり,アクションエディタのコメントのとりまと めと, 著者および外部審査者との連絡を担当した。外部審査者は, 著者に推薦を求め, 情報提供 があればそれを参考にした上で,アクションエディタが選定・依頼した。審査を依頼する際は, 通常の 依頼文のほかに, 本特集号の主旨を伝え, 審査が 2 段階にわたることなど通常の過程とは異なる点 が多々あること，その過程を辿ること自体に実践としての意味合いがあることをご理解いただけるよう に努めた。審査結果を著者に送付する際に審査者名を開示するかどうかは任意とし, 初回審査時 にそれぞれの審查者に判断を求めた。10 名のうち 5 名が顕名を選択した。なお,アクションエディタ は全員が顕名でコメントした。

第 1 段階審査の経過と結果を表 2 に示す。掲載可となったのは 3 編で, 受稿から受理までに要 した日数は短い順に 50 日，62 日，107 日であった。論文 1 は当初から審査結果がスプリットであり, 第 2 稿への審査コメントをふまえて, 第 3 稿の審査はアクションエディタのみで行った。2 編は著者に よる取り下げとなった。論文 2 は乳児, 論文 5 はラットを対象とする研究で, いずれも対象が非常に 限定されており, 必然的に, 必要なサンプルを確保することが極めて困難な研究であった。その点が 審査者にとっては採択可の判断を下寸ための必要条件となった一方で, 特集号の刊行タイミングも 決まっていることから，著者はそれに対応できないと判断するに至ったものである。

第 1 段階論文を事前登録する第三者機関としては Center for Open Science(COS)が運営するプ レプリントサーバ PsyArXivを利用した。著者自身のアカウントで登録・公開することを求め, 特集号 Web サイトからリンク寸ることで, 第 1 段階で採択された論文であることを公表した。

\section{表 2 第 1 段階審査の経過と結果}

\begin{tabular}{|c|c|c|c|c|c|c|c|c|c|c|c|}
\hline \multirow{2}{*}{ 論文ID } & \multirow{2}{*}{ 領域 } & \multicolumn{3}{|c|}{ 第1稿 } & \multicolumn{3}{|c|}{ 第2稿 } & \multicolumn{3}{|c|}{ 第3稿 } & \multirow{2}{*}{ 備考 } \\
\hline & & 受稿 & 審査完了 & 判定 & 受稿 & 審査完了 & 判定 & 受稿 & 審査完了 & 判定 & \\
\hline 1 & 認知 & $1 / 25$ & $2 / 28$ & $\mathrm{C} / \mathrm{A}$ & $3 / 10$ & $3 / 25$ & $C$ & $3 / 28$ & $3 / 28$ & 採択 & \\
\hline 2 & 発達 & $2 / 20$ & $3 / 27$ & $\mathrm{C} / \mathrm{C}$ & $4 / 23$ & $5 / 16$ & $\mathrm{C} / \mathrm{B}$ & & & & 取り下げ \\
\hline 3 & 臨床 & $2 / 26$ & $3 / 25$ & $\mathrm{~B} / \mathrm{B}$ & $4 / 15$ & $4 / 17$ & 採択 & & & & \\
\hline 4 & 社会 & $2 / 27$ & $3 / 28$ & $\mathrm{C} / \mathrm{B}$ & $4 / 29$ & $5 / 22$ & $B$ & $6 / 14$ & $6 / 14$ & 採択 & \\
\hline 5 & 学習 & $3 / 4$ & $4 / 2$ & $\mathrm{C} / \mathrm{B}$ & & & & & & & 取り下げ \\
\hline
\end{tabular}

注)判定は， A 採択可， B 多少修正すれば採択可。修正後の判断は審査担当編集委員に一任する。，C大幅な修正が必

要。修正後再審査する。，D採択不可から1つを選択している。

\section{第 2 段階審査}

第 2 段階審查の経過と結果を表 3 に示す。投稿された 3 編はいずれも掲載可となり, 受稿から受 理までに要した日数は短い順に 33 日, 58 日, 66 日であった。第 2 論文において, 第 1 段階論文 で分析プランに含まれていない探索的分析結果が追加されたケースもある。事前登録はこうした試 みを妨げるものではない, という立場から, 事前に計画された分析と探索的に行われた分析が明確 に区別されていれば, 追加されたこと自体は問題とせず, その内容を審査した。

論文 1 は, 第 1 段階論文の採択 (3 月 28 日)から第 2 段階論文の投稿 (10月 27 日)までに約 7 ケ月を要していることが分かる。これは事前登録で設定した必要サンプルサイズを充足する参加者

\footnotetext{
3 https://psyarxiv.com/
} 
数の確保に時間を要したものであり, その経緯は当該原著論文 (佐々木・米満・山田, 2020)に言及 がある。この件については，7 月末時点で著者から参加者確保が困難を極めており予定サンプルサ イズに到達しない可能性がある旨の申し出があった。担当編集委員で協議の結果, 事前登録時に 適切なサンプルサイズとして設定していた数が現実には集まらないというのは, 確かに予定とは異な る一方で, それだけのことでこの研究 (データ)を「お蔵入り」させるのは本末転倒であり, そうした過程 も含めてすべて明らかにして研究を公開することにこそ, プレレジの意義がある(つまりこの特集号の 趣旨に叶う)と判断して, 以下の 2 点を伝達した。結果的には, 必要サンプルサイズを充足したデー タによる第 2 論文が投稿された。

a) 第 2 論文の投稿 切を 10 月末に再設定する

b) 予定していたサンプルサイズに達さなかったとしてもその点については不問に付して, 第 2 段階 審査に進む

掲載可となった第 2 段階論文は, 第 1 段階論文と同じくPsyArXivで著者自身のアカウントにより プレプリントが公開され，特集号 Web サイトからリンクすることで, 掲載可 RR として公表した。

\section{表 3 第 2 段階審査の経過と結果}

\begin{tabular}{|c|c|c|c|c|c|c|c|c|c|c|}
\hline \multirow{2}{*}{ 論文ID } & \multirow{2}{*}{ 領域 } & \multicolumn{3}{|c|}{ 第1稿 } & \multicolumn{3}{|c|}{ 第2稿 } & \multicolumn{3}{|c|}{ 第3稿 } \\
\hline & & 受稿 & 審査完了 & 判定 & 受稿 & 審査完了 & 判定 & 受稿 & 審査完了 & 判定 \\
\hline 1 & 認知 & $10 / 27$ & $11 / 29$ & $A / B$ & $11 / 29$ & $11 / 29$ & 掲載可 & & & \\
\hline 3 & 臨床 & $8 / 5$ & $9 / 7$ & $\mathrm{C} / \mathrm{A}$ & $9 / 25$ & $9 / 27$ & B & $10 / 9$ & $10 / 10$ & 掲載可 \\
\hline 4 & 社会 & $8 / 16$ & $9 / 18$ & $\mathrm{~B} / \mathrm{B}$ & $10 / 9$ & $10 / 11$ & B & $10 / 12$ & $10 / 13$ & 掲載可 \\
\hline
\end{tabular}

注)判定は，A 採択可，B多少修正すれば採択可。修正後の判断は審査担当編集委員に一任する。，C大幅な修 正が必要。修正後再審査する。，D採択不可から1つを選択している。

\section{審査者の所感}

本特集号では, 10 名の方々に外部審査者としてご協力いただいた。巻頭言 (三浦ら，2020)で山 田氏が言及しているとおり, 事前登録の事前審査自体が日本の心理学系学術誌では初めてのケー スなので, 審査担当経験をもつ研究者もまたごく少数である。著者にも原著論文の中にこの方式の 意義や問題点に関寸る考察を含めることを歓迎したが, それと同様に, 審査者にもコメントを求めるこ とにした。ただし前述したとおり, 著者に対する審査者の顕名/匿名については審查者に選択を求め たが, 広く公開することについては事前に可否の選択を求めなかった。そのため, 公刊時に審査者 名を公開する学術誌があることは承知の上で, ここでは多くの先例に倣って審查者のお名前は匿名 とすることにした。

2019 年 11 月 19 日に, 審查者 10 名全員に 2019 年 12 月 10 日を期限として所感の寄稿を求 めた。コメントは, 事前登録の事前審査といらシステム自体へのコメント, それにより, 査読で悩まされ たこと, 考えさせられたことなどを中心にしていただくように依頼したが，特に制約はつけていない。ま た, コメントの対象によって紹介箇所を変える可能性はあるが, それ以外は改変を加えずすべてをそ のまま,ただし匿名で紹介寸る旨を依頼の際に説明した。結果的に第 1 段階で投稿された 5 編の審 查者から 1 名ずつ, 合計 5 名の方からコメントを頂戴することができた。著者への審査者名開示は, 3 名が顕名, 2 名が匿名であった。以下, コメントを受け取った順に紹介する。

\section{審査者 $A$ 氏}

まず, 事前登録の事前審査システムは素晴らしいシステムだと思う。普及されれば心理学における 
頑強な科学的知見の集積に貢献するシステムである。一方で, Science 誌に, 事前登録システムが 抱える困難を示す記事も掲載されている(Adam, 2019)。システム自体は先述のとおり素晴らしいが， 実施の際に顕在化する困難の解決が，今後，求められると思う。

次に, 查読で考えさせられたことについてコメントする。私は既に報告された知見の再現実験に関 する事前審查を行った。その際, どの要因までを既報と同じにするかという点で, 編集者および査読 者間で, 相違があると感じた。マウスの行動実験については, まったく同じ条件にしても，場所が変わ れば得られる值の絶対值が異なるといら論文がある(Crabbe, Wahlsten, and Dudek, 1999 )。また, ク ローズドコロニーのラットを使用する際に, line difference および litter effect は十分に考慮しなくて はいけないという論文がある(Ellenbroek, van den Kroonenberg, and Cools, 1998; Lehman, Pryce， and Feldon, 2000)。個人的な見解では, 再現性は, 厳密には, 異なる実験者が既報とまったく同じ 条件で実験を行い, 同じ結果が得られることで保たれると考えている。そのため, マウスやラットを対 象とした再現実験では, 週齢, 系統を揄えることはもちろん, 特にクローズドコロニーであれば, 飼育 業者まで同じにして行うべきだと考える。ただ，そこまでは揃えなくてよいという意見が，私以外に審査 に関わった方からあった。

この経緯を建設的にまとめると, 前者, つまり, 異なる実験者が既報とまったく同じ条件で実験を 行うタイプの再現実験は, 事実の確認という意味での再現性を担保するものであり, 後者, つまり, 実 施条件が多々異なるタイプの再現実験は, 既報で得られた事実がどこまで拡張して確認されるのか, という法則性の幅を確認する意味で, 再現性を担保する実験だったのだと思う。

最初に述べた「どの要因までを既報と同じにするかという点で, 編集者および查読者間で, 相違が ある」という点は，「再現性」という概念の幅の存在を示唆していると思う。これは「再現性の概念整理」 につながる重要なトピックだと思うので, 今後, 検討されるべきと感じた。

\section{審査者 $B$ 氏}

\section{第 1 段階審査}

これまでの查読で, その手法は良くない, という研究をいくつか見てきた。実験前に方法までを查 読することで, 手法の問題点を事前に議論できるので, 投稿者にとっては有益なことかもしれない。た だし, 今回のように查読によって条件がかえって厳しくなることもあるので, 投稿者はその点もある程 度覚悟しなければならないかもしれない。査読者の労力, という点については, 従来の査読と比較し て, 読む分量が少なくて済む(結果と考察がないので)。ターゲットとなる先行研究が査読者にとって 守備範囲でない場合, ターゲットとなる先行研究をしっかり読み込んで臨むことになるので, 場合によ ってはそれが査読者の負担になるかもしれない（今回のケースにおいては, 査読者として勉強させて いただいたので, 負担だとは思っていません)。

\section{第 2 段階審査}

「結果がどうなったか」ということをイチ早く読める, という楽しみがあることを感じた。また，「方法」に 関して既に十分議論しているので, 従来の査読と比較して安心して読める感じがした。

\section{査読者の名前をオープンにする}

従来の査読よりも, 責任を強く感じた。工学系の論文誌では著者名を伏せず, 査読者名は伏せ ている。今回のように, 著者名も査読者名もオープンにして查読することが良いことなのか, 自分の中 で考えがまとまっていないのだが, 少なくとも査読者名をオープンにすることで, 気の利いたコメントを しなければ, と思い, 查読することの責任をより感じた。もうお一人の査読結果を見て, 専門分野の違 いがあるにせよ, 自分の不勉強さを思い知らされた。查読者としての適性を試されている, という感じ 
がした。

\section{審査者 $\mathrm{C}$ 氏}

\section{事前登録の事前審査というシステム自体について}

事前登録の事前審査といらシステムは, 査読者に, 論文の可塑性が非常に高い状態での査読を 求めるものであると思えた。したがって, 査読者が投稿された論文に対してどこまでの変更を求めてよ いのか, 事前にルール化しておいてほしいと強く感じた。

\section{査読で悩まされたこと}

まず，通常であればリジェクトできる内容であっても，まだ実験・調査が実施されていないため，第 1 段階でのリジェクトを宣言するのが非常に難しい。目的がよほどおかしなものでない限り, 第 1 段階の 査読結果をもとに, 序論に(大幅に) 手を加え, 研究計画・研究方法・分析方法を適切なものに(大 幅に) 修正すれば, 当初投稿された際の論文の出来にかかわらず最終的には掲載に耐える内容に なるであろうと予測できる。今回は，特に，追試を目的とした論文であったため，「追試論文の選定が 不適切」以外の理由ではリジェクトのしようがないのではないかと思えた。

また，投稿者の論文構想が見えないため，序論の内容が，考察できちんと反映されるの かが判断しにくい。そのため, 第 1 段階の投稿で研究全体との関連が不明瞭な序論の記述 については,「もし当該部分が考察で活きないのであれば削除せよ」という指摘をせざるを 得ないが，このように指摘するということは，「投稿者が考察で活きないような無駄な情報 を序論で述べている」とほのめかすことになってしまう。しかし一方で，投稿者を信じて 「ここは考察で活かされるのだろう」と見逃した序論の記述が結局考察で活きなかったと しても, 第 2 段階の查読では序論への修正は要求できない。研究実施までのプロセスに影 響しない引用は序論から削除させるという強い信念が自分に必要だったと感じた。

前述した 2 点とも関連するが, どこまで修正要求をしてよいのかが判断しにくい。具体的には, 研 究計画・研究方法への修正要求の判断が非常に難しい。查読者の理解が足りないために不適当な 研究計画への修正を要求してしまったり, 查読者の要求に従って修正した研究計画が当初のものと はかけ離れてしまったり寸る可能性がある。研究の可塑性が高い分, 通常の査読よりも, 査読者のセ ンスとモラルが問われると感じた。たとえば, 研究計画・研究方法の骨子には修正を要求しない, もし 修正が必要であればリジェクトとする, というような基準がある方が, 査読者にとっても投稿者にとって も良いのではないかと思われた。

\section{査読で考えさせられたこと}

これは投稿者のスキルとモラルを信用した制度ではないだろうか, と感じた。事前登録の事前審査で は, 通常の査読と比べ, 研究計画, 研究方法の修正が可能である。これにより, 投稿者のスキルが 低い場合には, 査読が, 通常の査読がそうである以上に, 投稿者への指導になってしまう可能性が あるように思われる。第 1 段階で査読と修正を何往復も繰り返せば，いつかはそれなりの事前登録論 文になるであろうが，その分查読者の負担は莫大なものになりかねない。また，万が一投稿者のモ ラルが低い場合には，思いついた研究計画をとにかく文章にまとめて投稿してみて，査読 者に序論, 研究計画, 研究方法, 分析方法の修正点をすべて挙げさせ, それらを修正する という方法で, 研究の精緻化をアウトソーシングすることも不可能ではない。

これらの問題を解決する方法としては, 一定の基準に達していない投稿論文はできる限 り査読に回す前に編集委員会によってリジェクトする, 査読段階でのリジェクトの基準を 明確化する，の 2 点が重要であろうと考える。このうち，後者について言えば，たとえば 
「研究計画に大幅な修正が必要な場合にはリジェクトとする」「マイナーリビジョンのみ 可能とし，メジャーリビジョンは設けない」などのような基準があればよいと感じた。

さらに, 今回は追試研究の査読であったため, 主たる仮説自体は納得のできるものであった。よっ て, 仮説自体に対する評価はほとんどせずに済んだ。しかし, 追試研究ではなく, 新奇な現象を予 測する研究だったとしたら，仮説を導く理論展開あるいは仮説そのものが到底納得できないものであ った場合に,それでも公平に査読できたかどうかについては自信が持てない。

たとえばBem (2010) が事前登録されたものであったとして, 自分がその事前審查の查 読を担当した場合，これをリジェクトするのは，本当に公平な判断によるものだろうか。 何らかの理由で「そのような結果は得られそうにないと信じる」からリジェクトするのは, どこまで正当化しうるのか。たとえば，查読者の過去の主張に反する仮説だからリジェク 卜するというのは明らかに不当であろう。しかし，逆に，明らかに自然法則に反するよう な仮説を検討する研究を，ネガティブリザルトが得られると信じていながらアクセプトす るのは正当なのだろうか。結局, 事前登録の事前審査であったとして, (結果はネガティブ なものになっていたであろうが, ）Bem をリジェクトするべきであったのか, リジェクトすべきではな かったのか，考えれば考えるほどわからなくなってしまった。

\section{審査者 $D$ 氏}

事前登録論文の審査を行うのは今回が初めてでしたが, 追試方法についてどこまで指摘するべき かといら点が非常に悩ましく感じました。概念的追試では必ずしも先行研究と同じ方法を用いるわけ ではないため, 異なる結果が出た場合にはそれが再現性の問題によるものなのか, 方法の違いによ るものなのかを判断することが難しいです。そのため, 先行研究と異なる方法が提案されている場合, それが結果の再現性に影響しないかどうかを精查する必要があり, そのやり取りに余計な時間が掛 かってしまいます。通常の論文審査の場合には既に結果が出ており, 方法の違いに関してはその結 果をもって影響が無いことを示すことができますが, 事前登録論文ではそれが難しいため, 概念的追 試研究の審査にはあまり向いていないシステムのように思いました。

\section{審査者 $\mathrm{E}$ 氏}

本特集号における事前査読者を経験した感想を以下の 3 点記す。なお筆者は心理学における 再現性の危機に関して, 無知とは言わないまでも勉強不足の面があり, すでに周知であったり見当 違いのであったりするコメントがあればご容赦願いたい。

事前查読で最も難しかったのが,「その研究を行う意義がある」という点の評価である。筆者はこれ まで他雑誌でも查読経験があるが, そこで最も重視してきたのは,「結果」の部分で示されるデータで ある。そのデータが規則性のあるものであり,「方法」にも問題が無く, そしてそれらが「目的」や「考察」 での議論と適切にリンクしていれば，採択の方向性で査読結果を返してきた。これに対してデータが 示されていない事前登録・事前査読の場合, 採択の判定には, その研究をそもそも行う必要がある のかという「目的」部分の議論が大いに重要となる。分野が細分化されつつも分野横断型の研究も 増えている現代の心理学では, たとえ自分の専門分野であっても, 自分は知らないもののじつは重 要な研究というものが多々ある。そうした場合, 結局のところ, 建前的に言えば「目的」部におけるレビ ユーの良質さ, 本音的に言えば話の展開の上手さが，採択の判断に大きく関わってしまう。しかし一 方で, 再現性の危機をもたらした要因の一つは, そうした good story への過度な依拠ではなかった のだろうか。こうした点を考えると, 事前查読段階での採択の判定は, 心理学関連の学会発表の際 に求められるようなレベルの査読でも良いのかもしれない。しかしながら, すると学会発表なみに投稿 
数が増えてしまうかもしれず, また学術雑誌としての質の保証も問題になるだろう。こうした様々な要 因のバランスポイントの見極めは大変に難しいと感じた。

事前查読の利点と感じられたのは, 查読時の様々なコメントを研究計画に反映できる点である。再 現実験を例にして述べると, 先行研究では組み込まれていないものの, 通常その分野では組み込む べき統制条件やデータ分析法などが査読者より指摘されることで, 可能な限りそれらを組み込んだよ り良質な研究計画の下に再現実験を行うことができる。研究計画の段階での投稿であるので, 查読 者がこうしたコメントを行うことは容易である。これが通常の投稿論文であれば，すでに終えた研究に 対して,「○○についても考慮したほうが良かった, だから $\square \square$ 条件を含めてやり直しをせよ」とはなか なかコメントじらい。事前登録・事前査読は研究計画の公開であり,この方向性を活かすことはより 発展的な科学となるために重要であると感じた。

最後に問題点として挙げたいのは, 事前登録が過度な制約となってしまうことである。研究によっ ては, 当初想定してはいなかった付随的なデータが得られる場合がある。また, 手を変え品を変えデ ータを分析していたところ, 思いもかけず規則性が表れたということがあるだろう。しかしその研究は事 前登録をしており，そこではそうしたデータの存在や新たな分析方法を記していなかったとする。この 場合どうするべきだろうか。個人的には，「事前登録では記さなかったものの事後的に得られた」とい うことを正直に報告したうえで, そうしたデータを公表しても良いように思う。オープンサイエンスの発 想からも，また資金をかけて得られたデータを無駄にしないという視点からも，むしろそちらのほうが正 しいように思われる。事前登録の役割については, 事前登録の通りに実施しかつそれしか報告しない といら方向性よりも, 事前登録の通りにやりそれはそれで報告しつつ, それとは別枠としての追加の報 告も認め, その追加報告の価值に関してはその読者となる科学者共同体にゆだねるという緩い制約 のほうが発展的なように思われた。

以上, 本特集号に査読者として加わらせていただいた感想を記した。現代心理学において再現 性の危機とそれに対する心理学者共同体の制度改変は重要な問題であり, まさに心理学評論で扱 うべき問題であると考える。今後の議論のさらなる発展を期待したい。

\section{「事前登録の事前審査」の問題点}

コメントを寄せた 5 名の審查者が一様に述べているのが, 第 1 段階論文審査の難しさである。全 員が経験したことのなかった手続きなので戸惑いがあるのは当然ではあるが, 特に多く指摘されたの は，何を基準に適正な研究計画だと判断して研究着手を認めてよいかがわからない，といら点である。 従来の論文審查であれば，ある計画に沿って既に実施された結果を見た上でその手続きを確認す る。遡及的な修正はきかないので, 許容できるものでなければ掲載不可という判断を下すことになる。 一方, 事前登録論文の審査であれば修正を要求できるが, どこで折り合いをつければよいのかを図 りかねるのである。もちろん従来の查読でも似たような折り合いの難しさはあるものの, 研究着手前に それにあたるというのは, 審査者でありながら研究実施の責任を負うようなものである。また研究着手 前の手続きとしては研究倫理審査も同様の折り合いの難しさがあるかもしれないが, 倫理審査の対 象となるのは参加者保護を核とする倫理的な側面のみであるから, 重要ではあるが研究のうちごく限 定的なコンテンツに限られる。もちろん事前審査によって研究計画がブラッシュアップされ, より学術 的な意義が高まることは大いに期待できよう。しかし, 心理的な負担も, かかるコストも, 通常査読に 比して高いことは間違いあるまい。

また, 今回は対象を先行研究の直接的追試に限った。これは元来この特集号の扱うメタテーマが 
心理学研究の再現性問題であることに加えて, 著者が研究計画を立てるにせよ審査者が折り合い をつけるにせよ，先行研究というモデルがある方が着手が容易だろうという想定に基づくものであった。 しかしどの領域のどういう研究であれ, 心理学研究において「まったく同じ」研究を再現することはでき ない。一方で今のところ, 何を以て「直接的追試」と認めるのかに明確な規定や基準, あるいは合意 があるわけではない。前述したとおり, 今回の実践では対象とそのサンプルサイズに関わる問題が顕 著に表面化したが, 実験や調查の遂行に関わるすべての要素について同じ問題が発生する可能性 があり, そこには審查者 A 氏の言葉を借りれば「幅」が存在するのだろう。おそらくは, その幅の範囲 でケースごとに調整する以外の選択肢がない。その手続きに著者のみに委㸚るのではなく, 研究着 手前に審查者が著者と共に計画に関与することが「事前登録の事前審査」の核心であると同時に, もっとも困難な点であることを実感した。

第 2 段階の審査については, 事前登録どおりに研究が遂行されており, 探索的分析が含まれて いる場合はそれが予め計画されていたものと明確に切り分けられていれば, 結果がどうあれ掲載可と 寸る, という信念が共有されていれば, 大きな負担とはならないだろう。実際, 今回の審査所要日数 は 3 編とも約 1 ケ月であった。

これらの点をふまえると, RR 刊行を持続的に実施するためには, 様々な意味で外部審查者の負 担を軽減することが必要だと考えられる。そのためには, 第 1 段階審査での可否の基準をなるべく明 確にするようアクションエディタが努力し，積極的に審査過程をコントロールすることが必要だろう。ま た, 論文審査経歴を研究業績として現状より積極的に評価するのも有効かもしれない。そのために は，前述のとおり今回はそれをしなかったが，RR に携わった場合は必ず審查者を顕名にし，刊行時 に著者と共に併記することなどが考えられるだろう。

なお, 今回の実践では, 追試を手がけたのはいずれも単一の研究グループ, つまりシングルラボ追 試であった。このことが，本特集号に掲載された追試による再現性検証に一定の制約をつけているこ とは特記しておく必要がある。再現性検証の有力な方法としてメタ分析があり, それが同様の設定下 で実施された数多くの研究で得られた統計量を収集して統合的に分析し, 効果サイズを推定する手 法であることは周知であろう。これを一気に実施しようというのがマルチラボ追試で, Many Labs プロジ エクト(e.g. Klein et al., 2014) などがその典型である。本特集号では事前登録の事前審查による RR を刊行する試みに重点を置くために敢えて許容したが，1 編のシングルラボ追試で先行研究の再現 性に一定の結論を出すことは困難である。たとえそうであっても, RR を公刊し, その研究材料やデー タをオープンにすれば, 別の研究チームが追随しやすくなる。今回の試みが結果的にマルチラボ追 試による再現性検証につながる可能性に期待している。

\section{マルチラボ追試による RR の困 難さ}

上述のとおり, 心理学研究の少なくとも一部が向かうべきはマルチラボ追試による RR として公刊 することだ，というのが本特集号の立場である。そうであるだけに，そこにある大きな困難さについても 承知しておくべきであろう。ここでは, 比較認知科学分野でマルチラボ追試を実践している ManyPrimates プロジェクト4による招待論文(ManyPrimates，2020)を閲読した審查者 F 氏による所 感を紹介したい。このプロジェクトはヒト以外の動物を対象にした取り組みであるが，本特集号でも， 研究対象の限定性の高さと事前登録の事前審査との「相性の悪さ」が示されている。地道かつ発見

\footnotetext{
4 https://manyprimates.github.io/
} 
的な意味合いも含む従来型の研究スタイルと「新しいかたち」の良き共存も, 今後積極的に模索す べきだろう。

\section{審査者 $\mathrm{F}$ 氏}

これまで Manylabs による大規模追試プロジェクトや, その影響を受けた ManyBabies のことを傍か ら見ていましたが,この原稿を読むまで, 動物心理学領域における ManyPrimates という大規模追試 プロジェクトについて知りませんでした。動物研究から論文が 1 つ特集号に掲載されるのは本当に素 晴らしいです。この論文を読んで, 大規模追試の大変さを垣間見ることができました。今後, 動物心 理学の授業で話す話題の 1 つに加えたいと考えています。

ManyPrimates では, 研究の事前登録の後に実験をしているというのは驚かざるを得ません。研究 対象を霊長類に限定したこと, (少なくとも現在のところ) 訓練不要のプロトコルで, かつ少ない試行 数での実験に限定したことから実現可能になったのではないかと思います。今後, 動物の訓練を要 するような課題, つまり学習過程についての種間比較を含めた再現可能性に取り組んでいけるのか 期待は高まります。

ひるがえって, 自分の研究はどうなのかというと, 私はオープンサイエンスには積極的に取り組みを はじめたものの, 事前登録については, 二の足を踏んでいます。私の場合, 綿密に予備実験をし, そ れなりに計画を立てて実験を開始するのですが, 開始時点では, どれくらい動物の訓練に時間を要 寸るか, そもそも訓練がうまくいくのか, いつ終わるか不明なものがほとんどです。途中で計画の修正 を迫られるもの, 実験をしながら検討するものなど, 開始時に予測していない状況対処をすることが 多々あり, 事前登録ができる気がしません。今年の卒業研究の 1 つもそうだったのですが，6 月月ぼ 予備実験をして様々なことを事前に確認したうえで, 他の研究室の実験の追試から始めても, 論文 に書かれていない些末なところで動物の訓練がうまくいかず, 途中で軌道修正をかけています。事前 登録しようとすると, 軌道修正をかけたところで, 全部書き直しかと思うと, 自分の場合, 実験どころで はないだろうなと思います。

そうはいうものの, ヒトを対象とした実験も掲載されるような実験心理学の雑誌では, 論文投稿時に 事前登録された研究かを確認するものが増えてきました。動物を研究対象とする場合でも, ヒ卜の研 究同様に事前登録, 事前審査のようなものが適用されていくのか, そうなったときに動物を対象とした 心理学研究がそれらの動きについていけるのか, 自分なりに準備はしているのですが, 他の人の取り 組みの様子も気になるところです。

\section{終わりに}

Center for Open Science によれば,この論文を執筆している 2019 年 12 月 30 日現在, 世界の学 術誌のうち 217 誌が通常投稿あるいは特集企画で RR を受け入れている5。もちろん, 本特集号掲 載のIkeda et al.(2020)にあるとおり, 事前登録の事前審査とて QRPs 抑止について万能ではない。 いかなる制度も，それに則ることを定めた途端に抜け道探索が始まってしまうのを止めることはできな い。しかし，だからといって制度を定めることが無意味だといらことにはならないのもまた自明である。こ の「新しいかたち」が世の習いとなる将来を期待する。

\section{引用文献}

Adam, D. (2019). Psychology's reproducibility solution fails first test. Science, 364(6443), 813.

\footnotetext{
5 https://cos.io/rr/
} 
Bem, D. J. (2011). Feeling the future: Experimental evidence for anomalous retroactive influences on cognition and affect. Journal of Personality and Social Psychology, 100(3), 407-425.

Crabbe, J. C., Wahlsten, D., \& Dudek, B. C. (1999). Genetics of mouse behavior: interactions with laboratory environment. Science, 284(5420), 1670-1672.

Ellenbroek, B. A., van den Kroonenberg, P. T., \& Cools, A. R. (1998). The effects of an early stressful life event on sensorimotor gating in adult rats. Schizophrenia Research, 30(3), 251 260.

Ikeda, A., Xu, H., Fuji, N., Zhu, S., \& Yamada, Y. (2019). Questionable research practices following pre-registration. 心理学評論, 62(3).

Klein, R. A., Ratliff, K. A., Vianello, M., Adams, R. B., Jr., Bahník, Š., Bernstein, M. J., . . . Nosek, B. A. (2014). Investigating variation in replicability: A "many labs" replication project. Social Psychology, 45(3), 142-152.

Lehmann, J., Pryce, C. R., \& Feldon, J. (2000). Lack of effect of an early stressful life event on sensorimotor gating in adult rats. Schizophrenia Research, 41(2), 365-371.

ManyPrimates (2020). Collaborative open science as a way to reproducibility and new insights in primate cognition research. 心理学評論, 62(3).

三浦麻子・友永雅己・原田悦子・山田祐樹・竹澤正哲 (2020). 心理学研究の新しいかたち CHANGE we can believe in一特集号の刊行にあたって一心理学評論, 62(3).

佐々木恭志郎・米満文哉・山田祐樹 (2020). 利き手側の良さ一事前登録された Casasanto(2009) の直接的追試一心理学評論, $62(3)$. 